\title{
Selenium uptake and its antioxidant role in ryegrass cultivars as affected by selenite seed pelletization
}

\author{
P. Cartes ${ }^{1,2}$, L. Gianfreda ${ }^{3}$, C. Paredes ${ }^{1}$ and M.L. Mora ${ }^{1,2}$ \\ ${ }^{1}$ Center of Plant, Soil Interaction and Natural Resources Biotechnology, Scientific and Technological Bioresou- \\ rce Nucleus, Universidad de La Frontera, Casilla 54-D, Temuco, Chile. ${ }^{2}$ Departamento de Ciencias Químicas \\ y Recursos Naturales, Universidad de La Frontera, Casilla 54-D, Temuco, Chile. Dipartimento di Scienze del \\ Suolo, della Pianta, dell'Ambiente e delle Produzioni Animali, Università Degli Studi di Napoli Federico II, \\ Naples, Italy.*Corresponding author: pcartes@ufro.cl.
}

\begin{abstract}
A greenhouse study was carried out to evaluate the effect of seed pelletization with increasing selenite doses (from 0 to $60 \mathrm{~g} \mathrm{Se} \mathrm{ha}^{-1}$ ) on the yield, Se uptake and the antioxidant responses of three ryegrass cultivars (Aries, Nui and Quartet) cultivated on an Andisol during two consecutive growth periods. In addition, a second assay was conducted to determine the residual effect of Se in the shoots during four consecutive plant cuts. Results showed that selenite-pelleted seeds at rates up to $60 \mathrm{~g} \mathrm{Se} \mathrm{ha-1}$ did not influence the yield of shoots and roots of the three ryegrass cultivars. Selenium concentration in shoots and roots steadily increased as a consequence of increased Se supply, and it was accumulated mainly in the roots. Plants of the different cultivars accumulated similar amounts of Se in their shoots, but Quartet roots built up greater Se concentration than those of Aries or Nui at rates of application above $35 \mathrm{~g} \mathrm{Se} \mathrm{ha}^{-1}$. Whereas Se doses above $10 \mathrm{~g} \mathrm{ha}^{-1}$ increased the shoot Se concentration in the two yields of the three ryegrass cultivars to suitable levels according to the minimum dietary requirement of beef and dairy cattle, the residual effect of Se was maintained through four cuts at Se supply of 30 and $60 \mathrm{~g} \mathrm{ha}^{-1}$. Likewise, the different cultivars displayed differential patterns of lipid peroxidation in response to the added Se. During the growth period, reductions of the oxidative damage of membranes were accompanied by inhibition of SOD in Aries and Nui and by the activation of GSH-Px antioxidant enzymes in the three ryegrass cultivars. Thus, in our study the benefits of Se on the plant health were closely related to an enhancement of the antioxidant system in the ryegrass cultivars. In summary, our results indicate that selenite-pelleted ryegrass seeds seem to be a promissory tool to increase both the Se content and the antioxidant ability of pastures. Its potential use requires, however, to be evaluated under field conditions in Se deficient soils.
\end{abstract}

Keywords: GSH-Px, ryegrass, selenite, seed pelletization, SOD, TBARS 


\section{Introduction}

Since 1973, selenium (Se) has been of increased scientific interest for animal and human health, because it is an essential component of several proteins such as the antioxidant enzyme glutathione peroxidase (GSHPx) as well as other Se-containing enzymes, including iodothyronine deiodinases, thioredoxin reductase and selenoprotein W (Pallud et al., 1997; Birringer et al., 2002).

Selenium deficiency is overall distributed in soils around the world, including areas of Australia, China, Finland, New Zealand, North America and Sweeden (Gissel-Nielsen et al., 1984; Gupta and Gupta, 2000; Hartikainen, 2005), leading to clinical and subclinical signs in cattle grazing or fed with crops cultivated on these soils.

In the last decades, different approaches have been utilized to prevent Se deficiencies in ruminant nutrition. Thus, Se supplementation (selenite or selenate salts, elemental Se, or organic-Se) by either oral administration, additives in the diet, intra ruminal bullets or parenteral injection has been a common practice to improve the Se intake for livestock (Hemingway, 2003; Surai, 2006). Agronomic biofortification, through the application of Se-fertilizers, has also been successfully employed to raise the Se content of forages to sufficiency levels in different countries like Australia, Finland, and New Zealand (Whelan and Barrow, 1994; Oldfield, 1998; Hartikainen, 2005).

In Chile, over $60 \%$ of the beef and dairy production is developed on pastures of the South region, which is Se-deficient (Soil and Plant Laboratory database, La Frontera University). Nevertheless, in the Chilean market there are not either Se-fertilizers or Se-supplemented multinutrient fertilizers, and the metabolic disorders associated to low Se intake in grazing cattle (Wittwer et al., 2002) support the need to develop strategies for Se application in deficient pasture areas. In this sense, Mora et al. (2008) utilized the technology of seed pelletization with selenite to increase the Se content of white clover. However, this legume species seems to be very susceptible to Se toxicity. This fact could diminish the white clover contribution to grass-legume pastures and therefore the nutritional value of forage in the long-term.

On the other hand, although the current molecular knowledge does not support the Se essentiality for vascular plants (Terry et al., 2000), numerous studies have shown that at low concentration Se can exert a beneficial functions in plants, such as the improvement of growth (Hartikainen et al., 1997), the delay of the senescence (Xue et al., 2001) and the enhancement of the antioxidative system under UV irradiation (Hartikainen and Xue, 1999), high temperature (Djanaguiraman et al., 2010), seed desiccation (Pukacka et al., 2011), Cd (Pedrero et al., 2008; Filek et al., 2008) and Al stress conditions (Cartes et al., 2010).

Ryegrass is one of the most important forage species in terms of its contribution to the botanical composition of permanent pastures in Southern Chile, and we previously showed an increase of Se accumulation as well as non negative effect on the plant yield when Se was supplied at low concentration as selenite or selenate forms (Cartes et al., 2005). Moreover, this study also demonstrated that the effects of Se on ryegrass shoots were closely related not only with the Se dose but also with the Se source, being selenite more efficient than selenate to induce the activity of the antioxidant enzyme GSH-Px. These facts suggest that the use of selenite-pelleted ryegrass seeds could be evaluated as a strategic tool to raise the Se content of pastures cultivated on Se-deficient soils. In addition, plants differ considerably in their ability to accumulate and tolerate Se (Rani et al., 2005; Zhang et al., 2007), and differential Se uptake has been also ob- 
served among different ryegrass cultivars growing on a Se-deficient Andisol (Cartes, 2005), which denotes that the dynamics of Se accumulation and its antioxidant role require to be evaluated at the cultivar level.

The aim of this study was to evaluate the effect of seed pelletization with selenite on the yield, Se uptake and the antioxidant responses of different ryegrass cultivars grown on an Andisol under greenhouse conditions.

\section{Materials and methods}

\subsection{Greehnouse assays}

Ryegrass (Lolium perenne L.) plants of three cultivars (Aries, Nui and Quartet) were cultivated in a first greenhouse experiment. The assay was conducted on an Andisol (Freire Series of Southern Chile) never amended with Se-fertilizers. The soil chemical composition is shown in Table 1.

Table 1. Chemical properties of an Andisol of Southern Chile.

\begin{tabular}{ll}
\hline Parameter & Concentration* \\
\hline Organic matter $(\%)$ & $18 \pm 1$ \\
$\mathrm{P}\left(\mathrm{mg} \mathrm{kg}^{-1}\right)$ & $20 \pm 1$ \\
$\mathrm{~S}\left(\mathrm{mg} \mathrm{kg}^{-1}\right)$ & $12 \pm 1$ \\
$\mathrm{pH}\left(\mathrm{H}_{2} \mathrm{O}\right)$ & $5.38 \pm 0.01$ \\
$\mathrm{Ca}\left(\mathrm{cmol}+\mathrm{kg}^{-1}\right)$ & $14.13 \pm 0.05$ \\
$\mathrm{Mg}\left(\mathrm{cmol}+\mathrm{kg}^{-1}\right)$ & $1.75 \pm 0.02$ \\
$\mathrm{~K}\left(\mathrm{cmol}^{\mathrm{kg}} \mathrm{kg}^{-1}\right)$ & $0.90 \pm 0.02$ \\
$\mathrm{Na}\left(\mathrm{cmol}+\mathrm{kg}^{-1}\right)$ & $0.09 \pm 0.02$ \\
$\mathrm{Al}\left(\mathrm{cmol}+\mathrm{kg}^{-1}\right)$ & $0.02 \pm 0.01$ \\
Exchangeable cations & \\
$\left(\mathrm{cmol}+\mathrm{kg}^{-1}\right)$ & $16.87 \pm 0.07$ \\
$\mathrm{Al}$ saturation $(\%)$ & $0.12 \pm 0.01$ \\
\hline
\end{tabular}

* Data are means of three replicates \pm SD.
The soil chemical analysis was performed according with the methodology described by Sadzawka et al. (2004). Briefly, soil pH was assayed by potentiometry in a 1:2.5 (w/v) soil/ distilled water suspension. Organic matter was determined by wet digestion with a modified Walkley-Black method. Phosphorus was extracted by the Olsen bicarbonate method and analyzed as described by Murphy and Riley (1962). Sulfur was extracted with $\mathrm{Ca}\left(\mathrm{H}_{2} \mathrm{PO}_{4}\right)_{2}$ (Blakemore et al., 1987) and analyzed by turbidimetry (Tabatabai et al., 1982). Exchangeable $\mathrm{Ca}, \mathrm{Mg}, \mathrm{Na}$ and $\mathrm{K}$ were extracted with $1 \mathrm{M} \mathrm{CH}_{3} \mathrm{COONH}_{4}$ at $\mathrm{pH} 7.0$ and analyzed by Flame Atomic Absorption Spectrophotometry (FAAS). Exchangeable Al was extracted with 1 $\mathrm{M} \mathrm{KCl}$ and analyzed by FAAS.

For the experiment, one hundred and fifty seeds of each ryegrass cultivar were sown in each pot containing $2.2 \mathrm{~kg}$ soil previously fertilized with $200 \mathrm{mg}$ $\mathrm{P} \mathrm{kg}^{-1}$ soil (as Triple superphosphate) and $100 \mathrm{mg} \mathrm{S}$ $\mathrm{kg}^{-1}$ soil (as potassium magnesium sulfate $\left(\mathrm{K}_{2} \mathrm{SO}_{4} \mathrm{x}-\right.$ $2 \mathrm{MgSO}_{4}$ salt), Sulpomag). Before sowing, the seeds were pelleted with a mixture of $1 \%$ adhesive solution (Arabic gum), sodium selenite $\left(\mathrm{Na}_{2} \mathrm{SeO}_{3} \times 5 \mathrm{H}_{2} \mathrm{O}\right.$, MERCK reagent) and dolomite was used as coating material. Selenium was supplied to the seeds at rates equivalent to field applications of $0,5,10,15,20,25$, $30,35,40,45,50,55$ and $60 \mathrm{~g} \mathrm{ha}^{-1}$. Selenium doses were estimated according to the ryegrass seeding rate (25 $\mathrm{kg} \mathrm{ha}^{-1}$ ) commonly used in permanent pastures of Southern Chile. Three pots were used as replicates for each Se treatment. After germination, the assay was thinned to 80 seedlings per pot, and $50 \mathrm{mg} \mathrm{N} \mathrm{kg}^{-1}$ soil (as Urea) were applied. During the growth period, the plants were watered daily with distilled water. Two cuts of shoot biomass were harvested at $30 \mathrm{~cm}$ plant height, and at the end of the assay the roots were also collected. At harvest, plant yield and Se concentration were determined, and for each cut fresh shoots samples were taken to perform biochemical analyses. 
In addition, a second greenhouse experiment was carried out to determine the residual effect of the Se in the shoots of Aries and Quartet ryegrass cultivars in the long-term. For each cultivar, seeds were pelleted with selenite at three Se addition levels $(0,30$ and $60 \mathrm{~g} \mathrm{ha}^{-1}$ ), and three pots were used as replicates per each treatment. The assay was conducted on the Andisol previously characterized (Table 1), under the same growth conditions described above. Shoots were harvested during four consecutive cuts at $30 \mathrm{~cm}$ plant height, and subsequently shoot Se concentration was analyzed (see below).

\subsection{Plant selenium analysis}

The fresh weight (FW) of shoots and roots were recorded, and subsamples were dried at $65^{\circ} \mathrm{C}$ for $48 \mathrm{~h}$ to determine dry weight (DW) and Se concentration. For Se analysis, the samples (shoots or roots) were digested in an acid mixture (16 mL 65\% $\mathrm{HNO}_{3}, 2 \mathrm{~mL} \mathrm{70 \%}$ $\mathrm{HClO}_{4}$ and $2 \mathrm{~mL} \mathrm{95 \%} \mathrm{H}_{2} \mathrm{SO}_{4}$ ) until 2-3 $\mathrm{mL}$ of the solution were left (Kumpulainen et al., 1983). On the next day, $10 \mathrm{~mL}$ of $12 \% \mathrm{HCl}$ were added to each sample, and the mixture was boiled at $120^{\circ} \mathrm{C}$ for $20 \mathrm{~min}$ to reduce $\mathrm{Se}(+\mathrm{VI})$ to Se $(+\mathrm{IV})$. After cooling and filtration, every solution was made up to $15 \mathrm{~mL}$ with $12 \% \mathrm{HCl}$. Selenium concentration in each sample was measured by Atomic Absorption Spectrophotometry-Hydride Generation coupled (AAS-HG) by using sodium borohydride $\left(\mathrm{NaBH}_{4}\right)$ solution as the reducing agent. Two reference samples, obtained from the Department of Applied Chemistry and Microbiology of Helsinki University, were included in each analytical determination.

\subsection{Plant biochemical analyses}

\section{Lipid peroxidation measurements}

In the fresh shoot material, lipid peroxidation was assayed by measuring the thiobarbituric acid reactive substances (TBARS) according with the procedure modified by Du and Bramlage (1992). In this method, the absorbance of samples is measured at 532, 600 and $440 \mathrm{~nm}$ in order to correct the interferences produced by TBARS-sugar complexes.

\section{Enzyme assays}

Subsamples of fresh shoots were frozen in liquid nitrogen and stored at $-70^{\circ} \mathrm{C}$ to determine the activities of the antioxidant enzymes superoxide dismutase (SOD; EC. 1.15.1.1) and glutathione peroxidase (GSH-Px; EC. 1.11.1.9).

SOD activity was estimated by following the inhibition of the photochemical reduction of nitroblue tetrazolium (NBT). One SOD unit was defined as the amount of enzyme corresponding to $50 \%$ inhibition of the NBT reduction (Donahue et al., 1997). The reaction mixture contained $400 \mu \mathrm{L}$ of potassium phos-

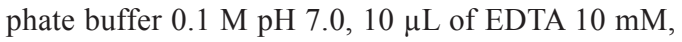
$50 \mu \mathrm{L}$ of metionine $260 \mathrm{mM}, 80 \mu \mathrm{L}$ of NBT $4.2 \mathrm{mM}$, $170 \mu \mathrm{L}$ of riboflavine $130 \mu \mathrm{M}$ and $300 \mu \mathrm{L}$ of supernatant. The absorbance of the samples was measured at $560 \mathrm{~nm}$, once the reaction tubes were illuminated for 15 minutes. Non illuminated and illuminated reactions without supernatant were used as controls.

GSH-Px activity was assayed by the modified method of Flohé and Gunzler (1984) by using $\mathrm{H}_{2} \mathrm{O}_{2}$ as substrate. The enzyme was extracted by the protocol described by Hartikainen et al. (2000) modified by the addition of $1 \mathrm{mM}$ EDTA and $1 \%$ poly(vinylpolypyrrolidone) as protease inhibitors. The absorbance of each sample was measured at 412 $\mathrm{nm}$ within $5 \mathrm{~min}$, and the enzyme activity was calculated as a decrease in GSH in the reaction time with respect to a non enzyme reaction.

SOD and GSH-Px activities were calculated on a protein basis. The protein concentration in the enzyme extracts was determined spectrophotometrically by the Bradford (1976) method. 


\subsection{Statistical analysis}

Data were analyzed using analysis of variance (ANOVA), and differences between means were separated with the LSD test at 0.05 significance level of probability. In addition, Pearson correlation was used to test the relationship among shoot Se concentration and plant biochemical responses.

\section{Results and discussion}

Even though several studies have proven that Se fertilizers efficiently increase the Se uptake in staple food crops, to our knowledge the use of selenite pelleted ryegrass seeds for agronomic biofortification purposes has not been evaluated yet. Furthermore, only few reports have examined the genotypic variation of crop species in terms of Se accumulation (Zhang et al.
2006; Zhao et al., 2009) and biochemical responses (Ramos et al., 2011) in plants subjected to Se supply.

In our experiment, selenite pelleted seeds at rates from 0 to $60 \mathrm{~g} \mathrm{ha}^{-1}$ progressively increased the amount of Se taken up by ryegrass Aries, Nui and Quartet (Figure 1a,b,c), and about 33 to $60 \%$ of the Se uptaken by plants was translocated from roots to shoots depending on both the ryegrass cultivar and the rate of Se application. Previous studies have also shown a low translocation of Se in plants treated with selenite (e.g. Hopper and Parker, 1999; Mora et al., 2008; Cartes et al., 2010) due to its ready assimilation into selenomethionine (and its oxide hydrate), Se-methylselenocysteine and/or several other unidentified Se species in the roots (Kahakachchi et al., 2004; Li et al., 2008). Nevertheless, the molecular and physiological mechanisms responsible of this behaviour require further research.
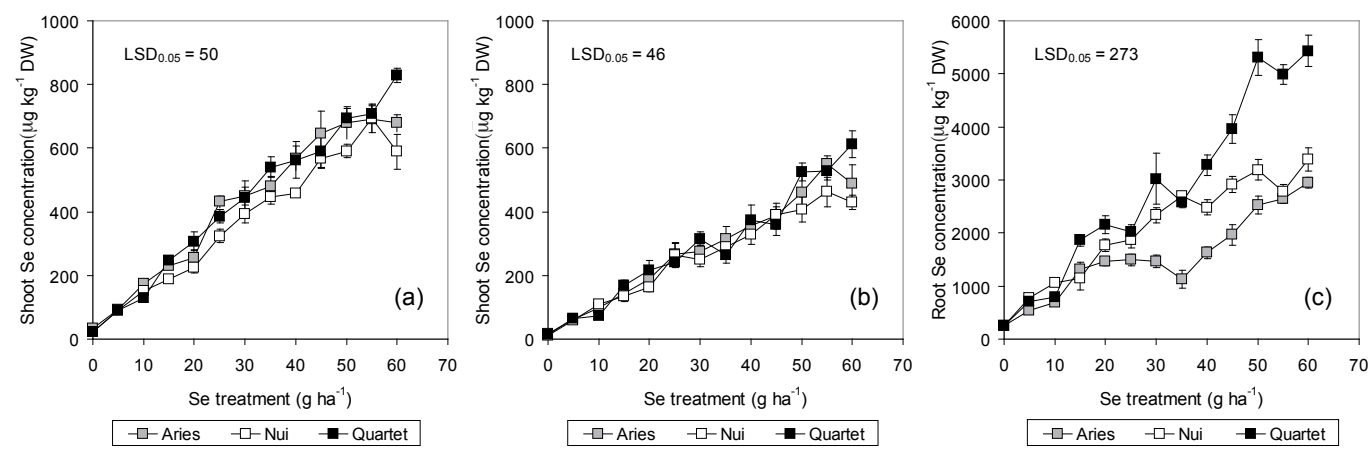

Figure 1. Selenium concentration in Aries, Nui and Quartet ryegrass cultivars subjected to selenite seed treatment at Se doses between 0 and $60 \mathrm{~g} \mathrm{ha}^{-1}$. (a) Shoots (first cut), (b) shoots (second cut) and (c) roots. Data are means of three replicates \pm SD. Statistical differences between treatments were tested at $p \leq 0.05$ (LSD test). 
In addition, Figure 1(a,b) shows that shoot Se concentration was similar among the three ryegrass cultivars at the first or second cuts, except in Quartet at $60 \mathrm{~g}$ Se $\mathrm{ha}^{-1}$ added that increased its Se accumulation by about $20 \%$ with respect to Aries or Nui at the two cuts. Quartet roots also accumulated more Se than Aries or Nui, especially at Se doses above $35 \mathrm{~g} \mathrm{ha}^{-1}$ (Figure 1c). In terms of plant yield, significant differences in shoot dry weight (DW) were only observed between cultivars (for each cut) and between cuts (for each cultivar) (Table $2, p \leq 0.05$ ). Thus, shoot DW was slightly higher in Quartet and Aries at the first and second cuts, respectively, and the yield was raised by about
38\% (Aries), 26\% (Nui) and 16\% (Quartet) at the second cut with respect to the first one. Likewise, Aries roots produced at least $29 \%$ more DW than Nui or Quartet roots. All together these results demonstrate that ryegrass cultivars accumulated differentially Se in their tissues, since non dilution effect as a consequence of increased dry matter production occurred in Aries or Nui when compared with Quartet. Furthermore, as expected we did not find any effect of Se supply on plant yield. Indeed, no differences in shoot DW of ryegrass Aries were found in a preliminary study at low selenite doses added directly to the seeds (Cartes, 2005).

Table 2. Dry weight (DW) of shoots (first and second cut) and roots of Aries, Nui and Quartet ryegrass cultivars subjected to selenite seed treatment at Se doses between 0 and $60 \mathrm{~g} \mathrm{ha}^{-1}$.

\begin{tabular}{llll}
\hline \multicolumn{1}{l}{ Ryegrass cultivar } & First cut & Second cut & \\
\hline Aries & $4.18 \pm 0.22$ & $5.75 \pm 0.20$ & Root DW $\left(\mathrm{g} \mathrm{pot}^{-1}\right)^{*}$ \\
Nui & $4.17 \pm 0.21$ & $5.24 \pm 0.25$ & $1.90 \pm 0.10$ \\
Quartet & $4.49 \pm 0.14$ & $5.21 \pm 0.22$ & $1.30 \pm 0.08$ \\
LSD $_{0.05}^{* *}$ & 0.32 & 0.49 & $1.34 \pm 0.11$ \\
\hline
\end{tabular}

* Data are means of three replicates $\pm \mathrm{SD}$.

** Statistical differences for shoots (first or second cut) or roots were tested at $p \leq 0.05$ (LSD test).

Even though shoot Se concentration decreased in the three ryegrass cultivars by about $27 \%$ at the second cut (Figure 1b), it is remarkable that at selenite addition levels above $10 \mathrm{~g} \mathrm{Se} \mathrm{ha}^{-1}$ plants accumulated in their shoots over $100 \mu \mathrm{g} \mathrm{Se} \mathrm{kg-1} \mathrm{DW,}$ which is the minimum nutritional requirement for beef and dairy cattle (NRC, 2000). Moreover, our results about the residual effect of Se in the long- term indicated that shoot Se concentration could remain at proper levels in ryegrass by at least four cuts at 30 or $60 \mathrm{~g} \mathrm{Se} \mathrm{ha}^{-1}$ supplied under greenhouse conditions (Figure 2). This fact denotes the need to investigate the efficacy of selenite-pelleted ryegrass seeds under field conditions, in order to increase the Se concentration in pastures developed on Se-deficient soils. 

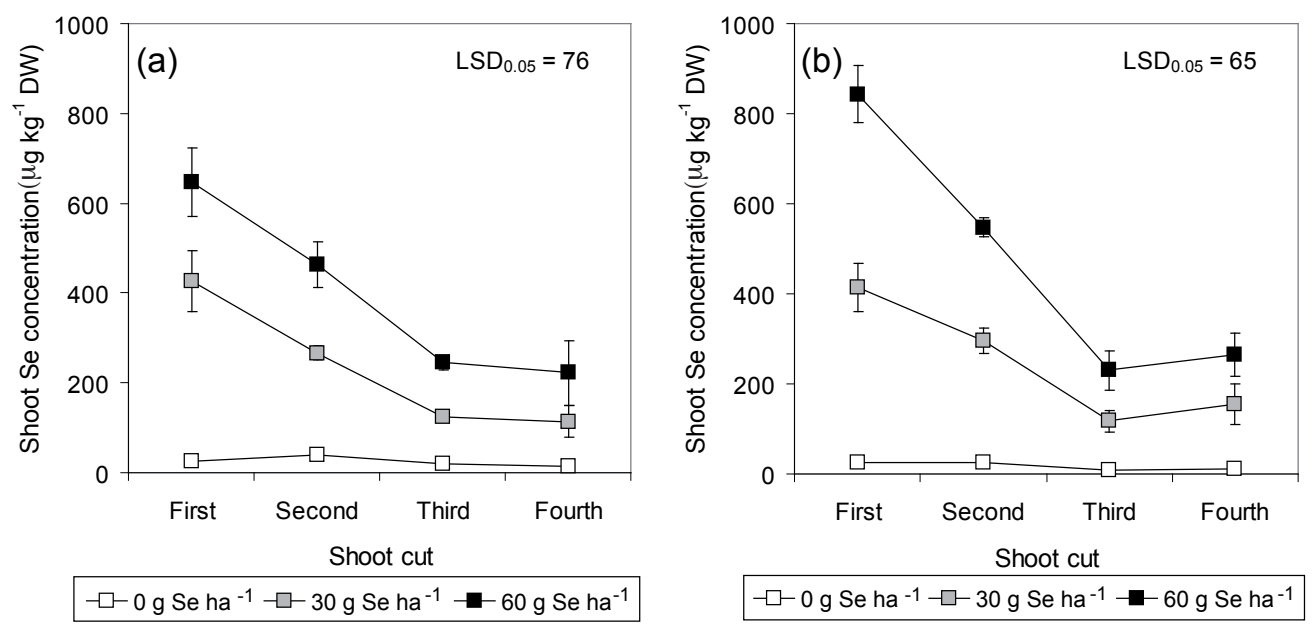

Figure 2. Selenium concentration during four consecutive cuts in the shoots of ryegrass cultivars subjected to selenite seed treatment at rates of application of 0,30 and $60 \mathrm{~g} \mathrm{Se} \mathrm{ha}^{-1}$. (a) Aries and (b) Quartet. Data are means of three replicates \pm SD. Statistical differences between treatments were tested at $p \leq 0.05$ (LSD test).

On the other hand, several reports have shown that cultivated plant species differ broadly in their ability to tolerate Se (Smith and Watkinson, 1984; Wu and Huang, 1992; Rani et al. 2005; Mora et al., 2008). Nevertheless, reports showing the impact of Se in plants at the cultivar level are scarce. From the point of view of oxidative damage and antioxidant enzyme activities, plants reacted dissimilarly to the seed treatment depending on both the ryegrass cultivar and the event of plant cut (Figure 3af). It is well known that during oxidative stress the overload of reactive oxygen species (ROS) can lead to the oxidative injury of biological membranes. Although the basal level of lipid peroxidation in the shoots of Aries or Nui remained unaltered at the first and second plant cuts, the TBARS amount of Quartet was the highest at the first cut (Figure 3a,b). Evidently, the seed pelletization procedure exerted initially some detrimental influence on lipid peroxidation in Quartet. However, it is noticeable the recovery from oxidative damage of Quartet plants at the second cut, reaching TBARS levels at least $35 \%$ lower than those of Aries or Nui at $0 \mathrm{Se}$ supply (Figure 3a,b). 

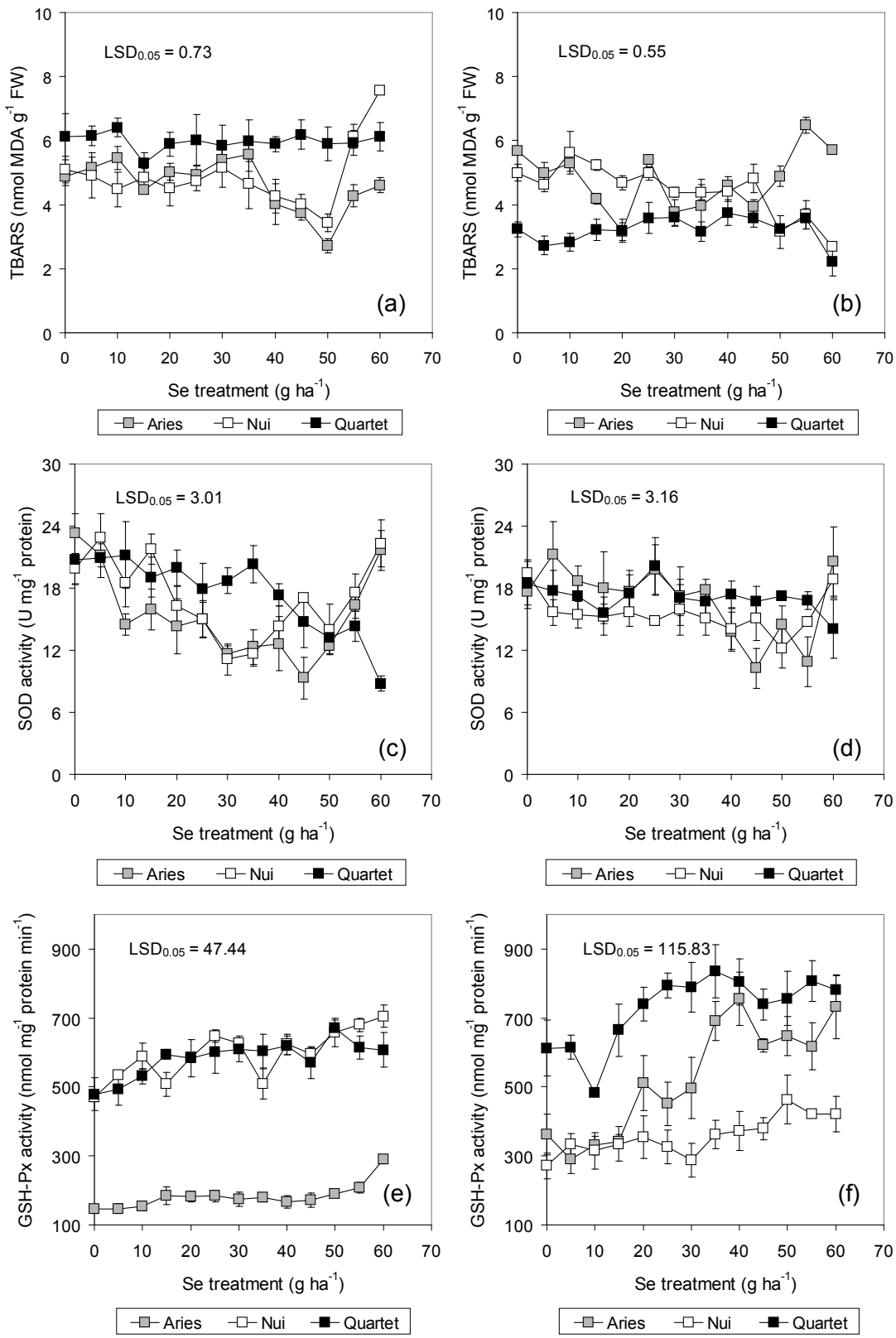

Figure 3. Lipid peroxidation, SOD activity and GSH-Px activity in the shoots of Aries, Nui and Quartet ryegrass cultivars subjected to selenite seed treatment at Se doses between 0 and $60 \mathrm{~g} \mathrm{ha}^{-1}$. (a), (c) and (e) correspond to biochemical measurements at the first cut. (b), (d), (f) correspond to biochemical measurements at the second cut. Data are means of three replicates \pm SD. Statistical differences between treatments were tested at $p \leq 0.05$ (LSD test). 
At the first cut, Aries and Nui exhibited a decrease of TBARS over $35 \mathrm{~g} \mathrm{Se} \mathrm{ha}^{-1}$ added as compared with plants grown without Se (Figure 3a). The maximum reduction of the peroxidative damage in both cultivars occurred at a rate of Se addition of $50 \mathrm{~g} \mathrm{ha}^{-1}$, which gave a shoot Se concentration of about $600 \mu \mathrm{g}$ Se $\mathrm{kg}^{-1}$ DW. However, above this Se dose a noticeable increase of shoot TBARS was observed. These results indicate that Se-induced oxidative stress occurred at the higher Se doses, especially in Nui that showed an increase of $49 \%$ in the lipid peroxidation level at $60 \mathrm{~g} \mathrm{Se} \mathrm{ha}^{-1}$ with respect to Se non-treated plants. Conversely, the amount of TBARS of Quartet shoots was not significantly altered by increasing Se supply. For the second cut, Se addition lowered TBARS accumulation in the shoots of Aries at rates of application below $50 \mathrm{~g} \mathrm{ha}^{-1}$. As compared with no Se addition, lipid peroxidation of ryegrass Nui was progressively decreased at increasing Se supply, reaching $46 \%$ TBARS decrease at a shoot Se concentration of about $430 \mu \mathrm{g} \mathrm{Se} \mathrm{kg}^{-1}$ DW (Figure 3b). The amount of TBARS did not vary significantly in the shoots of Quartet up to $55 \mathrm{~g} \mathrm{Se} \mathrm{ha}^{-1}$ applied. However, at the highest Se supply (which corresponded to a shoot Se

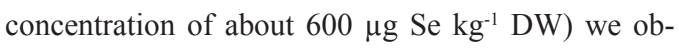
served a reduction of $31 \%$ in the oxidative damage of membranes with respect to $0 \mathrm{~g} \mathrm{Se} \mathrm{ha}{ }^{-1}$ seed treatment.
Ryegrass cultivars displayed differential activity patterns of SOD and GSH-Px antioxidant enzymes at the first or second cuts as a consequence of increasing selenite additions (Figure 3c-f). Fluctuations in the activity of these enzymes were also found between cuts for a same ryegrass cultivar. SOD enzyme acts in the first defense line against oxidative stress by reducing superoxide radicals, produced during the electron transport in different cell compartments, into $\mathrm{H}_{2} \mathrm{O}_{2}$ and oxygen (Alscher et al. 2002). During the first growth period, SOD activity in the shoots of Aries and Nui steadily diminished at Se supply up to 50 $\mathrm{g} \mathrm{ha}^{-1}$, but the enzyme was activated at the highest Se supply (Figure 3c). For both ryegrass cultivars, Se concentration in the shoots up to about $600 \mu \mathrm{g} \mathrm{kg}^{-1}$ DW inhibited SOD as demonstrated by the negative correlation between SOD and Se concentration (Table 3). Comparatively, an apparent inhibition of SOD was observed in Quartet at the first cut as a consequence of increasing Se addition levels, and a reduction of its activity of about $58 \%$ was noted at the greatest $\mathrm{Se}$ dose (Figure 3c). For the second cut, the effects of Se on SOD were less evident than for the first one. Thus, whereas non significant effect of Se on SOD activity was detected in Quartet (Figure 3d; Table 3), a slight decrease in its activity was found in Aries or Nui at $\mathrm{Se}$ addition levels below $60 \mathrm{~g} \mathrm{ha}^{-1}$. 
Table 3. Pearson correlations between shoot Se concentration and antioxidant enzymes activities (SOD or GSH$\mathrm{Px})$ in ryegrass cultivars subjected to selenite seed treatment at rates between 0 and $60 \mathrm{~g} \mathrm{Se} \mathrm{ha}^{-1}$.

\begin{tabular}{llll}
\hline & Aries & Nui & Quartet \\
\cline { 2 - 4 } Enzyme & \multicolumn{3}{c}{ Shoot Se concentration } \\
\hline & & First cut & \\
\hline SOD & $-0.441^{* *}$ & $-0.351^{*}$ & $-0.785^{* *}$ \\
GSH-Px & $0.612^{* *}$ & $0.697^{* *}$ & $0.688^{* *}$ \\
\hline & & Second cut & \\
\hline SOD & $-0.465^{* *}$ & -0.296 & -0.315 \\
GSH-Px & $0.772^{* *}$ & $0.610^{* *}$ & $0.576^{* *}$ \\
\hline
\end{tabular}

Asterisks indicate significance as follows: $* x \leq 0.05, * * p \leq 0.01$.

Even if the existence of essential Se-dependent proteins has not been demonstrated yet in vascular plants (Terry et al., 2000; Ellis and Salt, 2003), in agreement with previous reports (e.g. Hartikainen et al., 2000; Xue et al., 2001; Djanaguiraman et al., 2005), our results also revealed increased GSH-Px activity at the two cuts in the three ryegrass cultivars as response to applied Se (Figure 3e,f). Moreover, significant correlations between shoot Se concentration and GSH-Px activity were found at the first or the second cuts of the three ryegrass cultivars evaluated here (Table 3) supporting our earlier findings related to the benefits of selenite on the plant antioxidant system (Cartes et al., 2005). Nevertheless, GSH-Px activity of ryegrass cultivars responded differently between cuts (Figure 3e,f). Thus, GSH-Px was significantly activated in Aries at all Se supplies at the second cut with respect to the first one, and a similar trend was observed in ryegrass Quartet. However, the enzyme activity in the shoots of Nui was depressed in the second growth period irrespective of the Se addition level. Even though the physiological mechanisms responsible for such reduction of GSH-Px activity can not be clarified from the results of our study, it can be speculated that in Nui this enzyme might not have an essential role to detoxify $\mathrm{H}_{2} \mathrm{O}_{2}$ during the plant development. Nevertheless, the steadily reduction of lipid peroxidation in the shoots of Nui at the second cut (Figure 3b) suggests the benefits of selenite could be associated to activation of other complementary mechanisms to counteract oxidative stress such as the induction guaiacol peroxidase (POD) activity (Cartes et al., 2010) or the synthesis of antioxidant compounds (Ríos et al., 2009).

Interestingly, the shoot Se concentrations that could be considered as a threshold for Se toxicity in this experiment resulted considerably lower than those from our previous greenhouse studies with 
ryegrass plants grown on soil (Cartes et al., 2005) or hydroponics (Cartes et al., 2010). A possible explanation for this result could be a direct incidence of seed treatment with Se on the first stages of seedling development. It has been reported that cultivated plants are more susceptible to Se toxicity at early growth stages (Rosenfeld and Beath, 1964). Moreover, we have previously observed significant reductions in seedlings growth of different ryegrass cultivars in short-term plate experiments even at Se addition levels lower than $10 \mathrm{~g} \mathrm{Se} \mathrm{ha}^{-1}$ (data not shown). Nevertheless, if any harmful initial impact was presented at the highest Se addition level, it was rapidly overcame during the time course of the experiment as demonstrated by both the maintenance of plant yield at all the Se supply levels (Table 2) and the activation of the antioxidant enzymes at the first and second cuts (Figure 3c-f).

Although several studies have demonstrated the growth-promoting effect of low Se doses in ryegrass (Hartikainen et al., 2000), lettuce (Xue et al., 2001) and soybean (Djanaguiraman et al., 2005), in our study the benefits of selenite were associated rather to its antioxidant function as demonstrated by reduced lipid peroxidation (Figure 3a,b) and by the activation of GSH-Px enzyme (Figure 3e,f). Moreover, our results indicate that diminished lipid peroxidation was accompanied by a noticeable reduction of SOD activity in Aries and Nui (Figure 3c,d) supporting the hypothesis that at low concentration Se could diminish the need of SOD enzyme by contributing to improve the spontaneous dismutation of superoxide anions in some ryegrass cultivars (Hartikainen et al., 2000; Cartes et al., 2010).

\section{Conclusions}

Our results provide evidence that seed pelletization with selenite at rates from 5 to $60 \mathrm{~g} \mathrm{Se} \mathrm{ha}^{-1}$ progressively increased the Se uptake by Nui, Aries and
Quartet ryegrass cultivars without any negative impact on the plant yield during two consecutive shoot cuts. Likewise, it is remarkable that Se doses of 30 and $60 \mathrm{~g} \mathrm{ha}^{-1}$ raised the shoot Se concentration during four successive cuts over $100 \mu \mathrm{g} \mathrm{kg}^{-1} \mathrm{DW}$, which is the minimum nutritional requirement of beef and dairy cattle. In addition, dissimilar oxidative damage in cell membranes occurred among the ryegrass cultivars at increasing Se supply, and the beneficial role of Se was narrowly associated to an enhancement of the plant antioxidant system. Consequently, selenite-pelleted seeds appear to be a promissory tool to improve both the Se content and the antioxidant ability of ryegrass plants. However, its use requires to be evaluated under field conditions in Se-deficient areas.

\section{Aknowledgements}

This work was supported by the FONDECYT Projects 11080215 and 1100625 .

\section{References}

Alscher, R.G., Erturk, N., Heath, L.S. 2002. Role of superoxide dismutases (SODs) in controlling oxidative stress in plants. J. Exp. Bot. 53, 1331-1341.

Bradford, M. 1976. A rapid and sensitive method for the quantitation of microgram quantities of protein utilizing the principle of protein-dye binding. Anal. Biochem. 72, 248-254.

Ellis, D.R., Salt, D.E. 2003. Plants, selenium and human health. Curr. Opin. Plant Biol. 6, 273-279.

Birringer, M., Pilawa, S., Flohé, L. 2002. Trends in selenium biochemistry. Nat. Prod. Rep. 19, 693-718.

Cartes, P. 2005. Dinámica del selenio en el sistema suelo-planta: Evaluación de un sistema pratense modelo. Dr. Thesis. Universidad de La Frontera. Temuco, Chile. 123p. http://www.doctoradorrnn. ufro.cl/index.php?option=com_content\&view $=$ ar ticle\&id $=54 \&$ Itemid $=50$ 
Cartes, P., Gianfreda, L., Mora, M.L. 2005. Uptake of selenium and its antioxidant activity in ryegrass when applied as selenate and selenite forms. Plant Soil. 276, 359-367.

Cartes, P., Jara, A.A., Pinilla, L., Rosas, A., Mora, M.L. 2010. Selenium improves the antioxidant ability against aluminium-induced oxidative stress in ryegrass roots. Ann. Appl. Biol. 156, 297-307.

Djanaguiraman, M., Devi, D.D., Shanker, A.K., Sheeba, J.A., Bangarusamy, U. 2005. Selenium - an antioxidative protectant in soybean during senescence. Plant Soil. 272, 77-86.

Djanaguiraman, M., Prasad, P.V.V., Seppanen, M. 2010. Selenium protects sorghum leaves from oxidative damage under high temperature stress by enhancing antioxidant defense system. Plant Physiol. Bioch. 48, 999-1007.

Donahue, J.L., Okpodu, C.M., Cramer, C.L., Grabau, E.A., Alscher, R.G. 1997. Responses of antioxidants to paraquat in pea leaves. Relationships to resistance. Plant Physiol. 113, 249-257.

Du, Z., Bramlage, W.J. 1992. Modified thiobarbituric acid assay for measuring lipid oxidation in sugarrich plant tissue extracts. J. Agr. Food Chem. 40, 1566-1570.

Filek, M., Keskinen, R., Hartikainen, H., Szarejko, I., Janiak, A., Miszalski, Z., Golda, A. 2008. The protective role of selenium in rape seedlings subjected to cadmium stress. J. Plant Physiol. 165, 833-844.

Flohé, L., Gunzler, W.A. 1984. Assays of glutathione peroxidase. In: Parker, L. (ed). Methods in Enzymology. Academic Press, New York. Vol. 105. pp: 114-121.

Gissel-Nielsen, G., Gupta, U.C., Lamand, M., Westermarck, T. 1984. Selenium in soils and plants and its importance in livestock and human nutrition. Adv. Agron. 37, 397-460.
Gupta, U., Gupta, S. 2000. Selenium in soils and crops, its deficiencies in livestock and humans: implications for management. Commun. Soil Sci. Plant. 31, 1791-1807.

Hartikainen, H. 2005. Biogeochemistry of selenium and its impact on food chain quality and human health. J. Trace Elem. Med. Bio. 18, 309-318.

Hartikainen, H., Xue, T. 1999. The promotive effect of selenium on plant growth as triggered by ultraviolet irradiation. J. Environ. Qual. 28, 1372-1375.

Hartikainen, H., Xue, T., Piironen, V. 2000. Selenium as an anti-oxidant and pro-oxidant in ryegrass. Plant Soil. 225, 193-200.

Hartikainen, H., Ekholm, P., Piironen, V., Xue, T., Koivu, T., Yli-Halla, M. 1997. Quality of ryegrass and lettuce yields as affected by selenium fertilization. Agr. Food Sci. Finland. 6, 381-387.

Hemingway, R.G. 2003. The influences of dietary intakes and supplementation with selenium and vitamin $\mathrm{E}$ on reproduction diseases and reproductive efficiency in cattle and sheep. Vet. Res. Commun. 27, 159-174.

Hopper, J., Parker, D. 1999. Plant availability of selenite and selenate as influenced by the competing ions phosphate and sulfate. Plant Soil. 210, 199-207.

Kahakachchi, C., Boakye, H.T., Uden, P.C., Tyson, J.F. 2004. Chromatographic speciation of anionic and neutral selenium compounds in Se-accumulating Brassica juncea (Indian mustard) and in selenized yeast. J. Chromatogr. A. 1054, 303-312.

Kumpulainen, J., Raittila, A.M., Lehto, J., Koivistoinen, P. 1983. Electrothermal atomic absorption spectrometric determination of selenium in foods and diets. J. Assoc. Off. Ana. Chem. 66, 1129-1135.

Li, H.F., McGrath, S.P., Zhao, F.J. 2008. Selenium uptake, translocation and speciation in wheat supplied with selenate or selenite. New Phytol. 178, 92-102. 
Mora, M.L., Pinilla, L., Rosas, A., Cartes, P. 2008. Selenium uptake and its influence on the antioxidative system of white clover as affected by lime and phosphorus fertilization. Plant Soil. 303,139149.

Murphy, J., Riley, J.P. 1962. A modified single solution method for the determination of phosphate in natural waters. Anal. Chim. Acta. 27, 31-36.

National Research Council-NRC. 2000. Nutrients Requirements of Beef Cattle. Committee on Animal Nutrition. National Academy Press, Washington, DC. $232 \mathrm{p}$.

Oldfield, J.E. 1998. Environmental implications of uses of selenium with animals. In: Environmental Chemistry of Selenium. Eds. Frankenberger, W. T. and Engberg, R. A. Marcel Dekker, Inc. New York, USA. pp: 129-142.

Pallud, S., Lennon, A.M., Ramauge, M., Gavaret, J.M., Croteau, W., Pierre, M., Courtin, F., St. Germain, D.L. 1997. Expression of the type II iodothyronine deiodinase in cultured rat astrocytes is selenium-dependent. J. Biol. Chem. 272, 18104-18110.

Pedrero, Z., Madrid, Y., Hartikainen, H., Cámara, C. 2008. Protective effect of selenium in broccoli (Brassica oleracea) plants subjected to cadmium exposure. J. Agr. Food Chem. 56, 266-271.

Pukacka, S., Ratajczak, E., Kalemba, E. 2011. The protective role of selenium in recalcitrant Acer saccharium L. seeds subjected to desiccation. J. Plant Physiol. 168, 220-225.

Ramos, S.J., Rutzke, M.A., Hayes, R.J., Faquin, V., Guilherme, L.R.G., Li, L. 2011. Selenium accumulation in lettuce germplasm. Planta. 233, 649660 .

Rani, N., Dhillon, K.S., Dhillon, S.K. 2005. Critical levels of selenium in different crops grown in an alkaline silty loam soil treated with selenite-Se. Plant Soil. 277, 367-374.
Ríos, J.J., Blasco, B., Cervilla, L.M., Rosales, M.A., Sanchez-Rodriguez, E., Romero, L., Ruiz, J.M. 2009. Production and detoxification of $\mathrm{H}_{2} \mathrm{O}_{2}$ in lettuce plants exposed to selenium. Ann. Appl. Biol. 154, 107-116.

Rosenfeld, I, Beath, O. 1964. Selenium. Geobotany, Biochemistry, Toxicity and Nutrition. New York, Academic Press. 411 p.

Sadzawka, A., Carrasco, M., Grez, R., Mora, M.L. 2004. Métodos de análisis recomendados para los suelos chilenos. Comisión de Normalización y Acreditación (CNA) de la Sociedad Chilena de la Ciencia del Suelo. 113 p.

Smith, G.S., Watkinson, J.H. 1984. Selenium toxicity in perennial ryegrass and white clover. New Phytol. 97, 557-564.

Surai, P.F. 2006. Selenium in ruminant nutrition. In: Selenium in Nutrition and Health. Nottingham University Press, Nottingham, United Kingdom, pp. 487-587.

Tabatabai, M.A. 1982. Sulfur. In: Page, A.L., Miller, R.H., Keeney, D.R. (eds). Methods of soil analysis. Part 2: chemical and microbiological properties. American Society of Agronomy, Madison, WI, pp: 501-538.

Terry, N., Zayed, A.M., de Souza, M.P., Tarun, A.S 2000. Selenium in higher plants. Annu. Rev. Plant Phys. 51, 401-432.

Whelan, B.R., Barrow, N.J. 1994. Slow-release selenium fertilizers to correct selenium deficiency in grazing sheep in Western Australia. Fert. Res. 38, 183-188.

Wittwer, F., Araneda, P., Ceballos, A., Contreras, P.A., Andaur. M., Böhmwald, H. 2002. Actividad de glutatión peroxidasa (GSH-Px) en sangre de bovinos a pastoreo de la IX Región, Chile y su relación con la concentración de selenio en el forraje. Arch. Med. Vet. 34, 49-57. 
Wu, L., Huang, Z.-Z. 1992. Selenium assimilation and nutrient element uptake in white clover and tall fescue under the influence of sulphate concentration and selenium tolerance of the plants. J. Exp. Bot. 43, 549-555.

Xue, T., Hartikainen, H., Piironen, V. 2001. Antioxidative and growth-promoting effect of selenium on senescing lettuce. Plant Soil. 237, 55-61.

Zhang, L., Ackley, A.R., Pilon-Smits, E.A.H. 2007. Variation in selenium tolerance and accumula- tion among 19 Arabidopsis thaliana accessions. J. Plant Physiol. 164, 327-336.

Zhang, L.-H., Shi, W.-M., Wang, X.-C. 2006. Difference in selenium accumulation in shoots of two rice cultivars. Pedosphere. 16, 646-653.

Zhao, F.J., Su, Y.H., Dunham, S.J., Rakszegi, M., Bedo, Z., McGrath, S.P., Shewry P.R. 2009. Variation in mineral micronutrient concentrations in grain of wheat lines of diverse origin. J. Cereal Sci. 49, 290-295. 